\title{
A critical analysis of user satisfaction surveys in addiction services: opioid maintenance treatment as a representative case study
}

This article was published in the following Dove Press journal:

Patient Preference and Adherence

21 January 2014

Number of times this article has been viewed

\author{
Joan Trujols ${ }^{1,2}$ \\ loseba Iraurgi ${ }^{3}$ \\ Eugenia Oviedo-Joekes ${ }^{4,5}$ \\ Joan Guàrdia-Olmos ${ }^{6}$ \\ 'Unitat de Conductes Addictives, \\ Servei de Psiquiatria, Hospital de \\ la Santa Creu i Sant Pau, Institut \\ d'Investigació Biomèdica Sant Pau \\ (IIB Sant Pau), Barcelona, ${ }^{2}$ Centro \\ de Investigación Biomédica en \\ Red de Salud Mental (CIBERSAM), \\ Madrid, ${ }^{3}$ DeustoPsych - Unidad de \\ Investigación, Desarrollo e Innovación \\ en Psicología y Salud, Universidad \\ de Deusto, Bilbao, Spain; ${ }^{4}$ School \\ of Population and Public Health, \\ University of British Columbia, \\ ${ }^{5}$ Centre for Health Evaluation and \\ Outcome Sciences, Providence \\ Health Care Research Institute, \\ Vancouver, Canada; ${ }^{6}$ Departament \\ de Metodologia de les Ciències del \\ Comportament, Facultat de \\ Psicologia, Institut de Recerca \\ en Cervell, Cognició i Conducta \\ (IR3C), Universitat de Barcelona, \\ Barcelona, Spain
}

Correspondence: Joan Trujols Unitat de Conductes Addictives, Servei de Psiquiatria, Hospital de la Santa Creu i Sant Pau, Institut d'Investigació Biomèdica Sant Pau (IIB Sant Pau), Sant Antoni Maria Claret 167, 08025 Barcelona, Spain

Tel +34935537665

Fax +34 935537666

Email jtrujols@santpau.cat
Background: Satisfaction with services represents a key component of the user's perspective, and user satisfaction surveys are the most commonly used approach to evaluate the aforementioned perspective. The aim of this discursive paper is to provide a critical overview of user satisfaction surveys in addiction treatment and harm reduction services, with a particular focus on opioid maintenance treatment as a representative case.

Methods: We carried out a selective critical review and analysis of the literature on user satisfaction surveys in addiction treatment and harm reduction services.

Results: Most studies that have reported results of satisfaction surveys have found that the great majority of users (virtually all, in many cases) are highly satisfied with the services received. However, when these results are compared to the findings of studies that use different methodologies to explore the patient's perspective, the results are not as consistent as might be expected. It is not uncommon to find that "highly satisfied" patients report significant problems when mixed-methods studies are conducted. To understand this apparent contradiction, we explored two distinct (though not mutually exclusive) lines of reasoning, one of which concerns conceptual aspects and the other, methodological questions.

Conclusion: User satisfaction surveys, as currently designed and carried out in addiction treatment and harm reduction services, do not significantly help to improve service quality. Therefore, most of the enthusiasm and naiveté with which satisfaction surveys are currently performed and interpreted - and rarely acted on in the case of nonoptimal results - should be avoided. A truly participatory approach to program evaluation is urgently needed to reshape and transform patient satisfaction surveys.

Keywords: patient satisfaction, substance abuse treatment services, harm reduction services, patient-centered evaluation, service user perspective, user involvement

\section{Introduction}

Interventions and programs addressing drug use and related harms have traditionally been evaluated primarily by "hard" indicators or criteria, ${ }^{1}$ including program retention rates, use of the primary drug of abuse and other psychoactive substances, morbidity/ mortality, and criminal activity, among others. These criteria are relevant and necessary to inform health care policies; however, they do not necessarily reflect the priorities of those who use harm reduction or addiction treatment services. ${ }^{2,3}$ Moreover, there is evidence showing that user perspectives do not correlate with staff perspectives, ${ }^{4,5}$ a well-described phenomenon known as the "paradox of desynchrony." Therefore, it is clear that a more inclusive and comprehensive evaluation of the process and outcomes of interventions should include users' assessment of these variables. ${ }^{1}$ 
Satisfaction surveys, a key component of assessing the service user's perspective, ${ }^{7}$ have long been the most commonly used method of exploring this perspective. ${ }^{8}$ User satisfaction surveys assessing addiction treatment and harm reduction services have consistently found high skewness toward positive satisfaction scores. ${ }^{9-12}$ While this could be interpreted with great enthusiasm, other hypotheses should be considered, such as publication bias, lack of clarity of norms against which to compare the treatments, the psychometric properties of the instruments used, and the lack of an underlying theoretical framework of patient satisfaction. ${ }^{13,14}$ The aim of this paper is to provide a critical overview of user satisfaction surveys as currently carried out in addiction treatment and harm reduction services, with a special focus on opioid maintenance treatment (OMT) as a representative case. First, we argue the lack, relevance, and need for a more patient-centered approach to program evaluation. Then, we analyze the main features of client satisfaction surveys conducted at OMT centers as well as conceptual and methodological issues that may explain why the results of such surveys often diverge from results obtained via other data collection/generation methods. Finally, based on the discussion of some limitations of patient satisfaction surveys as currently performed, we suggest alternative directions for inquiry and research focused on a truly user-participatory approach to program evaluation.

\section{Towards a more user-centered approach to program evaluation}

When conducting a user-centered evaluation of OMT services, several indicators or assessment areas should be considered: a) user expectations and objectives for the treatment or intervention, ${ }^{15,16} \mathrm{~b}$ ) patient beliefs or opinions about medication (primarily methadone or buprenorphine), ${ }^{17-21}$ c) user appraisal of the relational dynamic with intervention providers ${ }^{22-24}$ and the degree of perceived participation in decision-making, ${ }^{25,26}$ as well as patient preferences for a participatory or deferential role, ${ }^{27,28} \mathrm{~d}$ ) indicators of userperceived quality, ${ }^{29}$ e) client perception of unmet needs,,${ }^{30,31}$ and f) level of satisfaction with treatment. ${ }^{8,11,25,32}$

Despite the relevance and validity of the aforementioned factors in facilitating adherence to the intervention ${ }^{10,33-35}$ and in measuring service quality, ${ }^{36,37}$ very few programs or centers evaluate these factors on a routine basis. This is surprising given that program adherence and service quality are two areas in which the importance of these variables is readily apparent. On one hand, these variables influence program acceptability and given that acceptability can affect adherence, these variables may mediate - at least partially - the efficacy of the interventions. On the other hand, the accreditation process of some types of treatment centers (eg, methadone treatment centers) requires the periodic evaluation of certain variables (generally, patient satisfaction) to assess quality. ${ }^{38,39}$

These variables (or more generally speaking, the user's perspective) have generally received scant attention ${ }^{40,41}$ and have been largely ignored by the community of mainstream researchers, ${ }^{42}$ who do not acknowledge the relevance of such variables in designing, providing, and/or evaluating addiction treatment and harm reduction services. This lack of research on user perspectives contrasts with the many studies evaluating interventions and treatments. This is particularly worrisome considering that input from service users is essential if we are to define, implement, and evaluate these interventions and programs, ensuring they meet the needs of the users themselves. ${ }^{43}$ Needless to say, a more in-depth understanding of user perspectives of interventions and centers would allow us to better interpret the efficacy and quality of interventions, as well as to plan and implement measures to improve those parameters. Without this knowledge, the risk of underestimating or distorting the value of treatment services to users through the usual assessment practices is high. ${ }^{44}$

In recent years, interest in including users' perspectives to evaluate interventions that address substance use appears to be growing. This interest has resulted in the increasing use of patient-reported outcome measures in both clinical trials and usual clinical practice. ${ }^{45-47}$ This emerging framework could be related to the current trend toward altering the traditional hierarchical relationship between health care professionals and patients, ie, a relationship based on the classical model of medical practice, which implies a biased and exclusionary perception of drug users as noncompetent persons. ${ }^{48,49}$

Satisfaction surveys, as stated above, are a key component of assessing the service user's perspective ${ }^{7}$ and are the most common and most studied approach to exploring the aforementioned perspective. ${ }^{8}$ Nevertheless, it is important to keep in mind that most classification systems of the opportunities or levels of participation in addiction treatment and harm reduction services consider user satisfaction surveys to be "low-involvement" activities (Table 1)..$^{50-52}$ In fact, some authors prefer to exclude user satisfaction surveys from the definition of participation because such surveys do not entail the existence of mechanisms to modify planning processes in response to the survey's findings, nor do they imply that service users participate as equal interlocutors. ${ }^{53}$ 
Table I Levels of user-participation or opportunities for user-participation in addiction treatment and harm reduction services

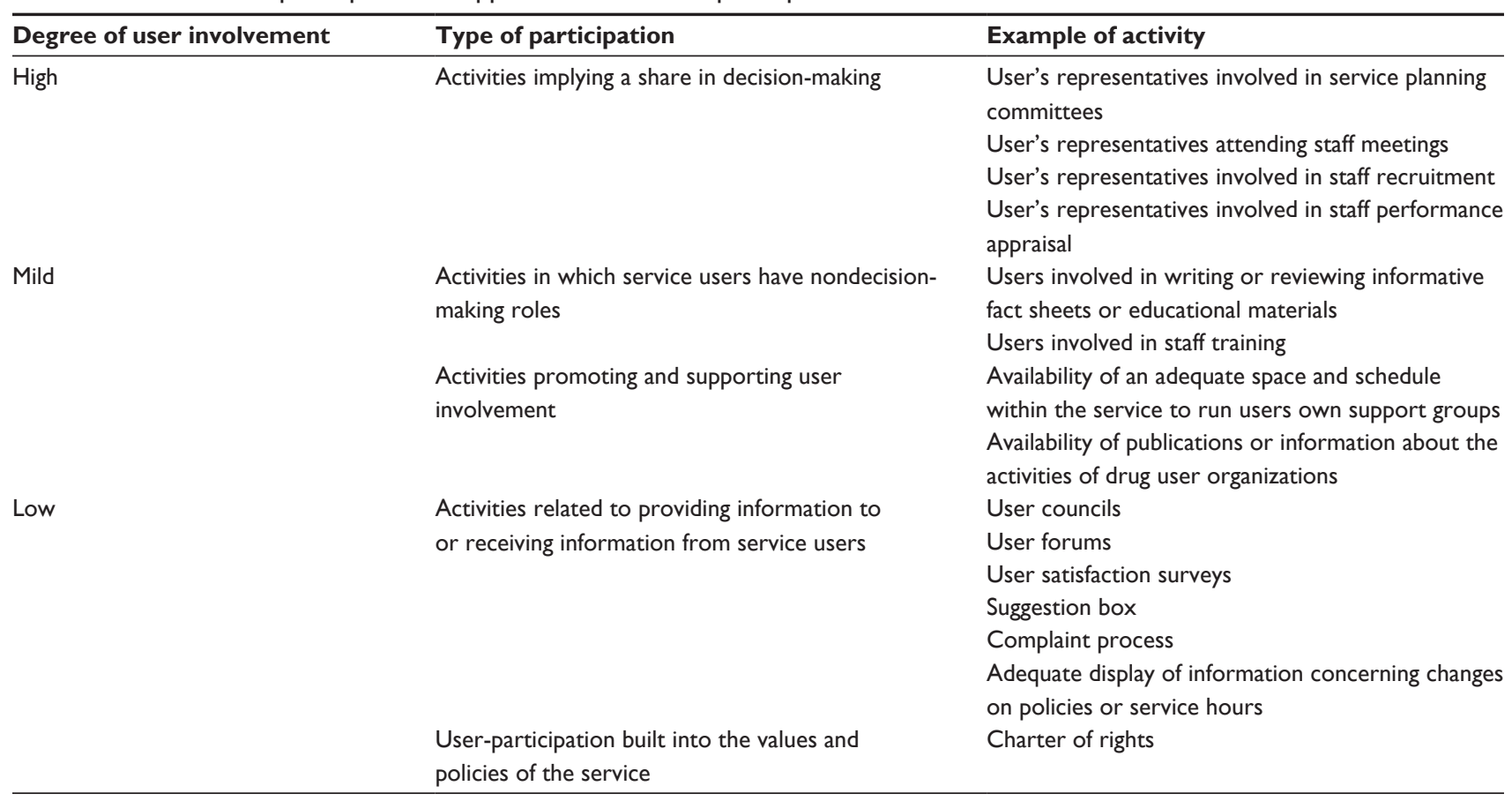

Notes: These levels represent a range of opportunities for user-participation. In practice, and due to very diverse reasons (eg, availability of the activity by the service or user's awareness and motivation), participation does not occur in all of these areas, in all services, or in the case of all users. Adapted with permission from Bryant J, Saxton $M$, Madden A, Bath N, Robinson S. Consumer participation in the planning and delivery of drug treatment services: the current arrangements. Drug Alcohol Rev. 2008;27(2): I30-137. Copyright @ 2009, John Wiley \& Sons. ${ }^{51}$

\section{Assessment of client satisfaction in OMT}

The number of validated self-reports specifically designed to assess satisfaction with addiction treatment ${ }^{54,55}$ and, more specifically, with treatment for opioid dependence, ${ }^{56,57}$ are quite limited. Client satisfaction with OMT has been primarily assessed through a) specific questions, ${ }^{58,59} \mathrm{~b}$ ) nonvalidated questionnaires designed ad hoc, ${ }^{60,61} \mathrm{c}$ ) nonvalidated adaptations of instruments originally designed to assess satisfaction with mental health services or other types of health care services, ${ }^{62}$ or d) validated generic scales designed to assess satisfaction with any type of health care center (ie, not specific to addictions). ${ }^{11,63-65}$

Patient satisfaction research conducted with instruments described above shows that most OMT clients (virtually all, in many cases) are highly satisfied with the care received. ${ }^{11,56,58,60,65}$ However, these findings clearly contradict a) specific comments made by particular OMT patients on many occasions and situations; ${ }^{66}$ b) most studies that have used a qualitative methodology to explore the views and experiences of OMT clients, the results of which are more nuanced, or in some cases, reflect a clearly ambivalent attitude toward OMT; ${ }^{6-69}$ and c) the results obtained by satisfaction surveys that include (in addition to items or a scale to evaluate satisfaction) either a list of potential problems or negative treatment-related aspects from which the respondent must select, or open-ended questions requiring a short response about which aspect(s) of the user's experience with the center he/she finds least satisfying. ${ }^{25,58,70}$ Interestingly, these latter mixed-method studies have allowed researchers to identify significant and/or frequent problems reported by clients who, concurrently, showed a high level of satisfaction with OMT.

To explain the reasons behind this apparent discrepancy, two distinct but nonexclusive arguments can be made: one line of argument is more closely related to conceptual aspects, while the other is mostly concerned with various methodological questions.

\section{Conceptual confusion between patient perceptions and patient satisfaction}

There is a conceptual confusion originating from the interchangeable use of the terms "patient satisfaction" and "patient perceptions." Satisfaction refers to the patient's perception of the extent to which his/her expectations, needs, or desires have been met. Satisfaction is thus, a particular kind of perception, but it is not the only one. ${ }^{71}$ This confusion has increased as most scales that assess satisfaction with addiction treatment have been developed without an underlying theoretical framework. Although various theoretical 
models of the "treatment satisfaction" construct exist, it seems to be assumed implicitly - and naively - that this is a construct with a universal meaning, or one that does not require greater clarification. ${ }^{72}$ In fact, some authors believe that the concept of treatment satisfaction seems to have been imposed on service users, with little consideration of its relevance. ${ }^{73}$ This situation is even more complex in the case of OMT, in which meanings linked to the construct of "patient satisfaction" and their respective operationalization can lead to even more confusion and ambiguity. For instance, from both a clinical and research perspective, it seems necessary to distinguish, at a minimum, between a) holding dose (ie, the dose that prevents subjective and objective opioid withdrawal symptoms over the 24-hour interdosing interval); b) dose adequacy (ie, the dose that allows patients not to use heroin, not to experience withdrawal symptoms nor heroin craving, not to show symptoms of overmedication, and in the case of heroin use, to hardly experience any subjective effects); c) satisfaction with medication; and d) satisfaction with treatment. ${ }^{74,75}$

Even when patients report a high degree of satisfaction with treatment, this does not necessarily entail that they have a similarly positive perception of the treatment received. High satisfaction scores can be due to negative initial expectations ${ }^{25,76}$ or may reflect, among other nonexclusive alternatives, beliefs of the type "they do the best they can" or "really, that is not their job", ${ }^{78}$ or service user preference to demonstrate a positive interaction with the people who care for them (social etiquette) ${ }^{79}$ or the limitations derived from the user's dependent position in the health care system. ${ }^{79}$ Given the consistently positive results from patient satisfaction surveys, it is no wonder that many authors believe these types of survey are little more than rhetorical practices that provide us with the comforting illusion that we are listening to patients, ${ }^{80}$ or that these surveys are mechanisms by which managers and clinicians seek to legitimize and maintain the status quo of treatment centers. ${ }^{69,81-83}$

\section{Methodological and procedural issues}

The second line of argument concerns diverse methodological and procedural issues related to satisfaction surveys.

\section{Unidimensional versus multidimensional approaches}

Patient satisfaction instruments can be classified according to factor structure as either unidimensional (ie, those that report a single overall satisfaction factor) or multidimensional (ie, comprised of several factors corresponding to differentiated facets or dimensions of treatment satisfaction). ${ }^{84,85}$
Dissatisfaction rates are, in general, higher in surveys that use multidimensional scales compared to those obtained with surveys that have used global or unidimensional instruments, ${ }^{85,86}$ although this comparison is not completely appropriate due to methodological differences arising from the type of instrument used.

\section{Affective versus factual focus}

Patient satisfaction scales can be divided into two types depending on the contents: factual measures (ie, objective reports) and affective measures (ie, subjective rating scales). ${ }^{85,87}$ Factual instruments, which are designed to avoid value judgments, focus on the service user's experiences. These types of instruments contain specific questions about those experiences in order to acquire objective data ("How often do you go to the center to take or pick up methadone?"; "How long after the scheduled appointment time do you usually have to wait to be seen?") or to verify whether certain processes and specific events have occurred or not ("Have the side effects of methadone been explained to you?"). In contrast, affective instruments focus on the patient's opinion about those experiences which reflects his/her preferences and expectations ("Do you think the frequency of your visits to the center to take/pick up methadone is excessive?"; "Are you satisfied with the waiting time between the scheduled appointment time and the actual start of the appointment?"; "Are you satisfied with the information you have received about the side effects of methadone?").

There is a lack of validated factual instruments among the satisfaction scales available for use in addiction treatment and harm reduction services. However, when such instruments do become available, it seems likely that the experience observed in other health care settings - ie, affective measures typically detect higher levels of satisfaction with treatment than factual instruments ${ }^{85,88}$ - will be repeated.

Affective self-report instruments, particularly those with a unidimensional factor structure, are unlikely to provide information that will be useful to improve health care. ${ }^{85,86,89}$ This is due to the way that most questions are formulated in these instruments; in many cases, it is not clear what elements, aspects, or processes need to be modified when a client's response indicates dissatisfaction, ${ }^{90,91}$ and it is even less clear how such changes should be effectuated. However, the use of multidimensional instruments (especially the factual measures) can remediate, at least partially, this weakness, as has occurred in other areas of health care. ${ }^{88,92,93}$ 


\section{Early drop-outs and refusals to participate}

We must not neglect a discussion of two important variables that have received insufficient attention in many of the patient satisfaction studies carried out to date in the addictions field: a) the number of early drop-outs from the program being evaluated ${ }^{81,85,94,95}$ and $b$ ) the nonresponse rate to the survey. ${ }^{26,96-99}$ Early drop-outs and no response could be reflecting low levels of satisfaction with treatment. These factors contribute to the uncertainty of the results obtained and are a threat to both the internal validity and generalizability of such results.

\section{A variant of the Hawthorne effect}

The Hawthorne effect is a positive and transitory change in a behavior being evaluated under experimental conditions. The change in behavior occurs not because of any alterations in the independent variable, but rather because participants know they are being observed or studied. ${ }^{100}$ By analogy, levels of satisfaction with treatment could, in some cases, reflect or be sensitive to this effect. Sitzia and Wood ${ }^{101}$ indicate that both the extra attention implicit in the process of data collection and the apparent interest in the user's level of satisfaction could lead to a positive perception of the service or center and, consequently, to higher scores.

\section{The phenomenon of response shift}

Finally, the response shift phenomenon ${ }^{102}$ merits discussion as a potential additional explanatory factor for the high levels of patient satisfaction typically observed. This phenomenon has been widely studied in the field of health-related quality of life, although it is equally relevant to any field that uses self-report instruments. ${ }^{103}$ Villar López et al ${ }^{104}$ highlighted the importance of response shift in evaluating satisfaction with treatment. The response shift phenomenon in health care settings refers to the process of adaptation to changes caused by the disease or treatment. ${ }^{103}$ More specifically, Sprangers and Schwartz ${ }^{102}$ define response shift as a change in the meaning of the self-evaluation of the target construct as a result of a) a change in the internal standards of measure (scale recalibration); b) a change in the values themselves - in other words, in the importance of the domains or components that make up the target construct (scale reprioritization); or c) a redefinition of the target construct (reconceptualization). Many years of substance use and a relatively long OMT could potentially modify the client's internal standards, values, and/ or concept of treatment satisfaction and, thereby, overestimate those levels of satisfaction.

\section{Future directions}

Most of the instruments currently available to assess user satisfaction with addiction treatment and harm reduction services are probably unable to adequately measure satisfaction due to how those instruments were developed. In general, the available instruments are based on a theoretical model that is often only vaguely defined and which evaluates areas of interest chosen by the researchers, service providers, or policy makers. ${ }^{105,106}$ It seems evident that self-reports developed in this manner are more likely to reflect the priorities of the clinicians, researchers, and/or administrators rather than those of the service users. ${ }^{101,107-109}$ This implies that questions about aspects of treatment and care that are relevant to patients would not be included, even though other variables that patients might consider irrelevant are incorporated. ${ }^{87}$ If true, to some extent this represents a threat to basic bioethical principles, such as autonomy, ${ }^{110}$ and to the validity of data gathered with these tools ${ }^{111}$ questioning the results obtained with these instruments.

Users of addiction treatment and harm reduction services - like users of any other health care services and programs - have a complex and highly nuanced experience that can be more appropriately and fruitfully captured via more generic, open-ended questions that are formulated in terms of the user's experience (not the satisfaction) with the service. Additional approaches include other qualitative techniques of data gathering, such as participant observation, ${ }^{112,113}$ focus groups,${ }^{31,67}$ or in-depth interviews. ${ }^{114-116}$ Likewise, the critical communicative methodology ${ }^{117-119}$ would seem to be particularly pertinent and promising in this area of research. Although the information provided by these methods can be extremely valuable for improving and redesigning interventions, a periodic quality assessment relying heavily on these approaches appears to be of questionable practicality under current circumstances.

The use of the critical communicative methodology or qualitative data gathering techniques must be an essential requirement for developing the much-needed new scales to measure treatment satisfaction ${ }^{120}$ or perception of treatment ${ }^{121}$ in a more patient-centered manner (Table 2). ${ }^{109,122} \mathrm{~A}$ genuinely patient-centered assessment of satisfaction with treatment will not be feasible without patients participating in the development of the instrument (eg, identifying the dimensions and variables to be assessed, drafting the items). Moreover, the aforementioned techniques should also play a major role in helping health professionals and researchers to directly, through the patient's own words, come to gain a thorough understanding of the patient's perspective (eg, expectations, 
Table 2 Classification of instruments to measure patient satisfaction according to the degree to which they incorporate the patient's own perspective

\begin{tabular}{|c|c|}
\hline Type & Description \\
\hline $\begin{array}{l}\text { Patient satisfaction } \\
\text { scale developed by patients }\end{array}$ & $\begin{array}{l}\text { A patient satisfaction scale (PSS) developed by patients (PSS-DP) is a PSS developed completely } \\
\text { from the patients' perspective. The main differentiating characteristic of this type of PSS lies in the } \\
\text { fact that all those involved in the different phases of its development are (or have been) recipients } \\
\text { of the service to be evaluated. }\end{array}$ \\
\hline Patient-centered satisfaction scale & $\begin{array}{l}\text { A patient-centered PSS (PSS-CP) is a PSS that explicitly incorporates, to a greater or lesser extent, } \\
\text { the patients' perspective. Even though other stakeholders (eg, clinicians, researchers, family } \\
\text { members, and/or administrators) have participated in developing the instrument, the patients } \\
\text { themselves have made major contributions, usually in the initial phases of I) generating the domains } \\
\text { or variables to be evaluated, } 2 \text { ) writing the questions, and/or } 3 \text { ) evaluating some characteristic of } \\
\text { the initial or pilot version of the instrument (eg, pertinence or comprehensibility of the items). }\end{array}$ \\
\hline $\begin{array}{l}\text { Patient satisfaction scale valued } \\
\text { by patients }\end{array}$ & $\begin{array}{l}\text { A PSS valued by patients (PSS-VP) is a PSS that, developed without direct patient participation, } \\
\text { is considered as such (ie, valued or appreciated) by most of them because it reflects, at least in } \\
\text { part, their perspectives. To determine whether a PSS developed without patient participation } \\
\text { can be considered patient-valued, qualitative research methods such as focus groups or cognitive } \\
\text { interviews must be performed. }\end{array}$ \\
\hline $\begin{array}{l}\text { Patient satisfaction scale irrelevant } \\
\text { to patients }\end{array}$ & $\begin{array}{l}\text { A PSS irrelevant to patients (PSS-IP) is a PSS that has been I) entirely developed without any patient } \\
\text { participation, and 2) assessed by patients as irrelevant or of no interest or value. A priori, assuming } \\
\text { no additional information is available, any PSS developed without any direct patient participation } \\
\text { should be placed, at least provisionally, in this category. }\end{array}$ \\
\hline
\end{tabular}

Note: Data from Trujols et al. ${ }^{122}$

perceived participation in decision-making). Having a deeper understanding of this perspective is an essential part of any efforts to improve the quality of addiction treatment and harm reduction services. This perspective cannot and should not be limited to user satisfaction with the service, and neither should user-participation in quality improvement efforts be restricted to answering a questionnaire. That said, if planners, managers, and workers involved in addiction treatment and harm reduction services are unwilling to make the necessary effort to achieve an in-depth understanding of users' perspective - and to act on any new insights obtained in the process - then these methodologies are unlikely to be implemented, and thus, authentic patient-centered satisfaction surveys will not be carried out.

Given this situation, it is not surprising that some authors, both in the drug-use intervention field ${ }^{8}$ as well as in other areas of health care ${ }^{123}$ pose this question: Do current satisfaction surveys form part of an emerging process of shared decision-making whose objective is to improve health care delivery and clinical care practices or, to the contrary, are such surveys a mere token gesture (ie, an empty ritual) ${ }^{124}$ from which no changes will emerge? In accordance, Madden et $\mathrm{l}^{25}$ affirm that "satisfaction surveys will be of only limited value in opioid treatment settings until there are agreed quality standards and formal mechanisms to educate consumers about their rights and the standards of care to which they are entitled". Without these changes and a commitment to act on the knowledge so acquired, it is unlikely that meaningful, rather than tokenistic, modalities of user involvement will be widely implemented in the near future. In fact, service users should not be asked to participate in a satisfaction survey if their input will amount to nothing. Moreover, it should be also emphasized that the aforementioned changes are unlikely to increase the right of service users to participate if their most basic needs are not met.

Patient participation should extend beyond assessing and improving the quality of care. The involvement of drug/service users in the design and implementation of specific programs and interventions, especially in the field of harm reduction, has been remarkable, with users, at times, displaying a higher level of competence than the public health institutions themselves. ${ }^{125-127}$ Similarly, considering that users' rights should not be limited to treatment needs alone, ${ }^{128,129}$ this dialogical and participatory dynamic should be extended to other areas such as addiction research ${ }^{130}$ and the development of drug policies. ${ }^{131}$

\section{Limitations}

The aim of this article was to provide a critical review of a comprehensive topic (ie, satisfaction with addiction treatment and harm reduction services) rather than a systematic examination of a focused research question. Therefore, a nonsystematic review was judged as the best approach for covering a wide range of issues relating to the topic reviewed. However, this approach implies not to systematically identify, select, appraise, and synthesize all research on the topic, 
representing a possible limitation of the present study. In any case, as several authors have pointed out, traditional narrative reviews are more appropriate for comprehensive topics and systematic reviews are better suited for focused topics. ${ }^{132}$ Additionally, our attempts to identify relevant studies went beyond the efforts usually made in narrative reviews. Spanning the last decade, our experience in research on satisfaction with addiction and harm reduction services ${ }^{5,8,11,26,29,32,57,58,74,75}$ has rendered us current on this topic. In this regard, the PubMed interface to search MEDLINE has been used. A search strategy favoring sensitivity over specificity is periodically performed using different combinations of addiction (eg, substance abuse, heroin, cocaine) or intervention-specific (eg, methadone, detoxification, needle exchange) terms and words related to the patient's perspective (eg, satisfaction, perception, view). In addition, reference lists included in the selected articles are normally examined for other relevant studies.

\section{Conclusion}

The current approach to user satisfaction surveys does not significantly contribute to the improvement of service quality. Therefore, most of the enthusiasm and naiveté with which user satisfaction surveys are currently conducted and interpretedand rarely acted on in cases of nonoptimal results - in addiction treatment and harm reduction services should be avoided. A truly participatory approach to program evaluation is needed urgently to reshape and transform patient satisfaction surveys. Similarly, there is a need to implement alternative research and quality-improvement initiatives that foster meaningful, rather than merely tokenistic, service user involvement. In turn, this will surely improve the relevance as well as the psychopolitical validity (both epistemic and transformative) ${ }^{133,134}$ of research and interventions in the substance use field.

\section{Acknowledgments}

This article is both dedicated, in memoriam, and profoundly indebted to Imma. This research received no specific grant from any funding agency in the public, commercial, or notfor-profit sectors. However, the article-processing charge was defrayed by a grant from the Banco de Instrumentos del Centro de Investigación Biomédica en Red de Salud Mental (CIBERSAM). An early draft of some of the ideas incorporated in this article was presented at the Encuentro FIPSE sobre Investigación de la Perspectiva Social del VIH/ SIDA (FIPSE Research Meeting on Social Perspectives on HIV/AIDS) (Valencia, Spain, November 26-28, 2006), and appeared in Tratado SET de trastornos adictivos (SET Handbook of Addictive Disorders). ${ }^{135}$

\section{Author contributions}

Joan Trujols and Ioseba Iraurgi conceived of and designed the present study, counting on advice from Eugenia OviedoJoekes and Joan Guàrdia-Olmos. Joan Trujols wrote the initial draft and led the writing of subsequent versions. All authors commented on and significantly contributed to the successive drafts. All authors read and approved the final version submitted for publication.

\section{Disclosure}

The authors state that they have been involved in the design, implementation, analysis, and/or reporting of satisfaction survey studies, whether or not cited in the current manuscript. Joan Trujols also declares to be a member of the team of researchers who adapted the Verona Service Satisfaction scale for methadone treatment programs; this adaptation is, in any case, in the public domain. Authors do not consider these facts to constitute actual or potential conflicts of interest with respect to the submitted manuscript but include the information for completeness and transparency. The views expressed are those of the authors and do not necessarily represent nor reflect those of the organizations or institutions in which they work. The authors report no other conflicts of interest in this work.

\section{References}

1. Iraurgi I. Evaluación de Resultados en Trastornos Adictivos: Calidad de Vida Como Indicador y Puntuación Fiable de Cambio Como Estimador [Outcomes Assessment in Addictive Disorders: Quality of Life as an Indicator and Reliable Change Index as an Estimator] [doctoral thesis]. Donostia-San Sebastián: Universidad del País Vasco (UPV/EHU); 2010. Spanish.

2. De Maeyer J, Vanderplasschen W, Broekaert E. Exploratory study on drug users' perspectives on quality of life: more than health-related quality of life? Soc Indic Res. 2009;90(1):107-126.

3. Treloar C, Holt M. Complex vulnerabilities as barriers to treatment for illicit drug users with high prevalence mental health co-morbidities. Ment Health Subst Use. 2008;1(1):84-95.

4. Pulford J, Adams P, Sheridan J. Client/clinician discrepancies in perceived problem improvement and the potential influence on dropout response. Int J Ment Health Addict. 2009;7(4):497-505.

5. Trujols J, Siñol N, Iraurgi I, Batlle F, Guàrdia J, Pérez de Los Cobos J. Patient and clinician's ratings of improvement in methadone-maintained patients: Differing perspectives? Harm Reduct J. 2011;8(1):23.

6. Bilsbury CD, Richman A. A staging approach to measuring patient-centred subjective outcomes. Acta Psychiatr Scand Suppl. 2002;414:5-40.

7. Ruggeri M, Tansella M. To what extent do mental health services meet patients' needs and provide satisfactory care? Curr Opin Psychiatry. 2002;15(2):193-199.

8. Trujols J, Pérez de los Cobos J. La perspectiva de los usuarios sobre los tratamientos de mantenimiento con metadona: Una revisión centrada en la satisfacción con el tratamiento [Users' views of methadone maintenance treatment: a review focused on satisfaction with treatment]. Adicciones. 2005;17(2):181-204. Spanish.

9. Carlson MJ, Gabriel RM. Patient satisfaction, use of services, and oneyear outcomes in publicly funded substance abuse treatment. Psychiatr Serv. 2001;52(9):1230-1236. 
10. Hser YI, Evans E, Huang D, Anglin DM. Relationship between drug treatment services, retention, and outcomes. Psychiatr Serv. 2004:55(7):767-774.

11. Marchand KI, Oviedo-Joekes E, Guh D, Brissette S, Marsh DC, Schechter MT. Client satisfaction among participants in a randomized trial comparing oral methadone and injectable diacetylmorphine for long-term opioid-dependency. BMC Health Serv Res. 2011;11:174.

12. Ries RK, Jaffe C, Comtois KA, Kitchell M. Treatment satisfaction compared with outcome in severe dual disorders. Community Ment Health J. 1999;35(3):213-221.

13. Crow R, Gage H, Hampson S, et al. The measurement of satisfaction with healthcare: implications for practice from a systematic review of the literature. Health Technol Assess. 2002;6(32):1-244.

14. Lehman AF, Zastowny TR. Patient satisfaction with mental health services: a meta-analysis to establish norms. Eval Program Plann. 1983;6(3-4):265-274.

15. Koester S, Anderson K, Hoffer L. Active heroin injectors' perceptions and use of methadone maintenance treatment: cynical performance or selfprescribed risk reduction? Subst Use Misuse. 1999;34(14): 2135-2153.

16. Ning AM. Games of truth: rethinking conformity and resistance in narratives of heroin recovery. Med Anthropol. 2005;24(4):349-382.

17. Guichard A, Lert F, Brodeur JM, Richard L. Rapports des usagers au Subutex $^{\circledR}$ : de la reconquête de l'autonomie à la spirale de l'échec [Drug users' relationships with Subutex ${ }^{\circledR}$ : from restored independence to the downward spiral of failure]. Sci Soc Sante. 2006;24(4):5-43. French.

18. Kayman DJ, Goldstein MF, Deren S, Rosenblum A. Predicting treatment retention with a brief "opinions about methadone" scale. J Psychoactive Drugs. 2006;38(1):93-100.

19. Kelly SM, Brown BS, Katz EC, et al. A comparison of attitudes toward opioid agonist treatment among short-term buprenorphine patients. Am J Drug Alcohol Abuse. 2012;38(3):233-238.

20. Schwartz, RP, Kelly SM, O'Grady, KE, et al. Attitudes toward buprenorphine and methadone among opioid-dependent individuals. Am J Addict. 2008;17(5):396-401.

21. Stancliff S, Myers JE, Steiner S, Drucker E. Beliefs about methadone in an inner-city methadone clinic. J Urban Health. 2002;79(4):571-578.

22. Guichard A, Lert F, Brodeur JM, Richard L. Buprenorphine substitution treatment in France: drug users' views of the doctor-user relationship. Soc Sci Med. 2007;64(12):2578-2593.

23. Lilly R, Quirk A, Rhodes T, Stimson GV. Juggling multiple roles: staff and client perceptions of keyworker roles and the constraints on delivering counselling and support services in methadone treatment. Addict Res Theory. 1999;7(4):267-289.

24. Quirk A, Lilly R, Rhodes T, Stimson G. Negotiating a script: the dynamics of staff/client relationships. In: Tober G, Strang J, editors. Methadone Matters: Evolving Community Methadone Treatment of Opiate Addiction. London: Martin Dunitz; 2003:33-43.

25. Madden A, Lea T, Bath N, Winstock AR. Satisfaction guaranteed? What clients on methadone and buprenorphine think about their treatment. Drug Alcohol Rev. 2008;27(6):671-678.

26. Trujols J, Garijo I, Siñol N, del Pozo J, Portella MJ, Pérez de los Cobos J. Patient satisfaction with methadone maintenance treatment: the relevance of participation in treatment and social functioning. Drug Alcohol Depend. 2012;123(1-3):41-47.

27. Bryant J, Saxton M, Madden A, Bath N, Robinson S. Consumers' and providers' perspectives about consumer participation in drug treatment services: is there support to do more? What are the obstacles? Drug Alcohol Rev. 2008;27(2):138-144.

28. Fischer J, Neale J. Involving drug users in treatment decisions: an exploration of potential problems. Drugs Educ Prev Policy. 2008;15(2): $161-175$.

29. March Cerdá JC, Martín-Ruiz E, Oviedo-Joekes E, Rivadeneira Sicilia A, Rodríguez Reinado C. Percepción de usuarios de los programas de tratamiento con metadona sobre la accesibilidad y atención recibida de los equipos terapéuticos [Methadone treatment programme users' perception of the accessibility and care received from the therapeutic teams]. Adicciones. 2006;18(4):359-369. Spanish.
30. Apantaku-Olajide T, Ducray K, Byrne P, Smyth BP. Perception of unmet needs and association with benzodiazepine misuse among patients on a methadone maintenance treatment programme. Psychiatrist. 2012;36(5):169-174.

31. Fountain J, Strang J, Griffiths P, Powis B, Gossop M. Measuring met and unmet need of drug misusers: integration of quantitative and qualitative data. Eur Addict Res. 2000;6(2):97-103.

32. Pérez de los Cobos J, Fidel G, Escuder G, et al. A satisfaction survey of opioid-dependent clients at methadone treatment centres in Spain. Drug Alcohol Depend. 2004;73(3):307-313.

33. Kelly SM, O`Grady KE, Brown BS, Mitchell SG, Schwartz RP. The role of patient satisfaction in methadone treatment. Am J Drug Alcohol Abuse. 2010;36(3):150-154.

34. Kelly SM, O`Grady KE, Mitchell SG, Brown BS, Schwartz RP. Predictors of methadone treatment retention from a multi-site study: a survival analysis. Drug Alcohol Depend. 2011;117(2-3):170-175.

35. Villafranca SW, McKellar JD, Trafton JA, Humphreys K. Predictors of retention in methadone programs: a signal detection analysis. Drug Alcohol Depend. 2006;83(3):218-224.

36. Bell J. Quality improvement for methadone maintenance treatment. Subst Use Misuse. 2000;35(12-14):1735-1756.

37. McLellan AT, Chalk M, Bartlett J. Outcomes, performance, and quality: what's the difference? J Subst Abuse Treat. 2007;32(4):331-340.

38. Casas M, Callao R, Cañellas J, et al. Indicadors de qualitat per a l'avaluació externa de centres d'atenció i seguiment en drogodependències [Quality indicators for an external evaluation of drug treatment services]. Barcelona: Direcció General de Drogodependències i Sida del Departament de Sanitat i Seguretat Social de la Generalitat de Catalunya; 2001. Spanish.

39. Substance Abuse and Mental Health Services Administration. Federal guidelines for opioid treatment (Revision draft). Rockville, MD: Substance Abuse and Mental Health Services Administration; 2013. Available from: http://www.dpt.samhsa.gov/pdf/FederalGuidelinesfo rOpioidTreatment5-6-2013revisiondraft_508.pdf. Accessed July 25, 2013.

40. Ball JC, Graff H, Sheehan JJ. The heroin addicts' view of methadone maintenance. Br J Addict Alcohol Other Drugs. 1974;69(1):89-95.

41. Hunt G, Barker JC. Drug treatment in contemporary anthropology and sociology. Eur Addict Res. 1999;5(3):126-132.

42. Montagne M. Appreciating the user's perspective: listening to the "methadonians". Subst Use Misuse. 2002;37(4):565-570.

43. Trujols J, Salazar JI, Salazar I. Los usuarios de drogas como ciudadanos: Los programas de reducción de daños [Drug users as citizens: the harm reduction programmes]. In: Becoña E, Rodríguez A, Salazar I, editors. Drogodependencias V. Avances [Drug dependence V Advances]. Santiago de Compostela: Universidad de Santiago de Compostela; 1999:343-378. Spanish.

44. Treloar C, Fraser S, Valentine K. Valuing methadone takeaway doses: the contribution of service-user perspectives to policy and practice. Drugs Educ Prev Policy. 2007;14(1):61-74.

45. Cella D, Yount S, Rothrock N, et al; PROMIS Cooperative Group. The Patient-Reported Outcomes Measurement Information System (PROMIS): progress of an NIH Roadmap cooperative group during its first two years. Med Care. 2007;45(5 Suppl 1):S3-S11.

46. Hilton TF. The promise of PROMIS ${ }^{\circledR}$ for addiction. Drug Alcohol Depend. 2011;119(3):229-234.

47. Pilkonis PA, Yu L, Colditz J, et al. Item banks for alcohol use from the Patient-Reported Outcomes Measurement Information System (PROMIS): use, consequences, and expectancies. Drug Alcohol Depend. 2013;130(1-3):167-177.

48. Heller D, McCoy K, Cunningham C. An invisible barrier to integrating HIV primary care with harm reduction services: philosophical clashes between the harm reduction and medical models. Public Health Rep. 2004;119(1):32-39.

49. Treloar C, Holt M. Deficit models and divergent philosophies: service providers' perspectives on barriers and incentives to drug treatment. Drugs Educ Prev Policy. 2006;13(4):367-382. 
50. Australian Injecting and Illicit Drug Users League. Treatment service users project: Phase two final report. Canberra: Australian Injecting and Illicit Drug Users League; 2011. Available from: https://csrh.arts. unsw.edu.au/media/NCHSRFile/9_AIVL_TSU_Project_Phase_Two_ Final_Report_2011.pdf. Accessed July 25, 2013.

51. Bryant J, Saxton M, Madden A, Bath N, Robinson S. Consumer participation in the planning and delivery of drug treatment services: the current arrangements. Drug Alcohol Rev. 2008;27(2):130-137.

52. Schulte S, Moring J, Meier PS, Barrowclough C. User involvement and desired service developments in drug treatment: service user and provider views. Drugs Educ Prev Policy. 2007;14(3):277-287.

53. Simpson EL, House AO. User and carer involvement in mental health services: from rhetoric to science. Br J Psychiatry. 2003;183(2):89-91.

54. Marsden J, Nizzoli U, Corbelli C, et al. New European instruments for treatment outcome research: reliability of the maudsley addiction profile and treatment perceptions questionnaire in Italy, Spain and Portugal. Eur Addict Res. 2000;6(3):115-122.

55. Marsden J, Stewart D, Gossop M, et al. Assessing client satisfaction with treatment for substance use problems and the development of the treatment perceptions questionnaire (TPQ). Addict Res Theory. 2000;8(5):455-470.

56. Barry DT, Moore BA, Pantalon MV, et al. Patient satisfaction with primary care office-based buprenorphine/naloxone treatment. $J$ Gen Intern Med. 2007;22(2):242-245.

57. de los Cobos J, Valero S, Haro G, et al. Development and psychometric properties of the Verona Service Satisfaction Scale for methadonetreated opioid-dependent patients (VSSS-MT). Drug Alcohol Depend. 2002;68(2):209-214

58. Markez I, Iraurgi I, Póo M. Programas de mantenimiento con metadona en el País Vasco: dispositivos específicos y oficinas de farmacia [Methadone maintenance programs in the Basque Country: specific centers and pharmacy offices]. Trastornos Adictivos. 2002;4(3):171-180. Spanish.

59. Zhang Z, Gerstein DR, Friedmann PD. Patient satisfaction and sustained outcomes of drug abuse treatment. J Health Psychol. 2008;13(3):388-400.

60. Kumar MR, Rajwal M. Survey of client satisfaction with methadone maintenance programmes. Psychiatrist. 2006;30(1):16-18.

61. Stone E, Fletcher K. User views on supervised methadone consumption. Addict Biol. 2003;8(1):45-48.

62. Fiellin DA, O'Connor PG, Chawarski M, Pakes JP, Pantalon MV, Schottenfeld RS. Methadone maintenance in primary care: a randomized controlled trial. JAMA. 2001;286(14):1724-1731.

63. Deering D, Horn J, Frampton CM. Clients' perceptions of opioid substitution treatment: an input to improving the quality of treatment Int J Ment Health Nurs. 2012;21(4):330-339.

64. King VL, Kidorf MS, Stoller KB, Schwartz R, Kolodner K, Brooner RK. A 12-month controlled trial of methadone medical maintenance integrated into an adaptive treatment model. J Subst Abuse Treat 2006;31(4):385-393.

65. Ward J. The Case of Community Methadone Treatment Programs. In: World Health Organization, editor. Workbook 6 Client Satisfaction Evaluations. Genève: World Health Organization; 2000:32-38. Available from: http://www.emcdda.europa.eu/attachements.cfm/att_5868_EN_6_ client_satisfaction_evaluations.pdf. Accessed November 7, 2013.

66. Crawford MJ, Kessel AS. Not listening to patients - the use and misuse of patient satisfaction studies. Int J Soc Psychiatry. 1999;45(1):1-6.

67. Fischer B, Chin AT, Kuo I, Kirst M, Vlahov D. Canadian illicit opiate users' views on methadone and other opiate prescription treatment: an exploratory qualitative study. Subst Use Misuse. 2002;37(4): 495-522.

68. Neale J. Drug users' views of prescribed methadone. Drugs Educ Prev Policy. 1998;5(1):33-45.

69. Williams B. Patient satisfaction: a valid concept? Soc Sci Med. 1994;38(4):509-516

70. Andrew S, Salamonson Y, Everett B, Halcomb EJ, Davidson PM. Beyond the ceiling effect: using a mixed methods approach to measure patient satisfaction. Int J Mult Res Approaches. 2011;5(1):52-63.
71. Sofaer S, Firminger K. Patient perceptions of the quality of health services. Ann Rev Public Health. 2005;26:513-559.

72. Collins K, Nicolson P. The meaning of 'satisfaction' for people with dermatological problems: reassessing approaches to qualitative health psychology research. J Health Psychol. 2002;7(5):615-629.

73. Edwards C, Staniszewska S. Accessing the user's perspective. Health Soc Care Community. 2000;8(6):417-424.

74. Trujols J, Siñol N, de los Cobos JP. Methadone maintenance treatment: the need to distinguish between holding dose, dose adequacy, satisfaction with methadone as a medication, and satisfaction with treatment. J Clin Psychopharmacol. 2010;30(1):95-96.

75. Trujols J, Iraurgi I, Siñol N, Portella MJ, Pérez V, Pérez de los Cobos J. Satisfaction with methadone as a medication: psychometric properties of the Spanish version of the treatment satisfaction questionnaire for medication. J Clin Psychopharmacol. 2012;32(1):69-74.

76. Bath N, Madden A. When you can't see the wood for the trees: what does drug treatment consumer satisfaction really tell us? Psychol Subst Use Newsl. 2006;6(2):3-5. Available from: http://www.groups.psychology. org.au/Assets/Files/psu_newsletter_july2006.pdf. Accessed November 27, 2013.

77. Dawson R, Spross JA, Jablonski ES, Hoyer DR, Sellers DE, Solomon MZ. Probing the paradox of patients' satisfaction with inadequate pain management. J Pain Symptom Manage. 2002;23(3):211-220.

78. Williams B, Coyle J, Healy D. The meaning of patient satisfaction: an explanation of high reported levels. Soc Sci Med. 1998;47(9): 1351-1359.

79. Edwards C, Staniszewska S, Crichton N. Investigation of the ways in which patients' reports of their satisfaction with health care are constructed. Sociol Health Illn. 2004;26(2):159-183.

80. Avis M. Incorporating patients' voices in the audit process. Qual Health Care. 1997;6(2):86-91.

81. Bartu A. Client satisfaction: why bother? J Subst Use. 1996;1(1): 20-26.

82. Harrison S, Mort M. Which champions, which people? Public and user involvement in health care as a technology of legitimation. Soc Policy Adm. 1998;32(1):60-70.

83. Hodge S. Participation, discourse and power: a case study in service user involvement. Crit Soc Policy. 2005;25(2):164-179.

84. Attkisson CC, Greenfield TK. The UCSF client satisfaction scales: I. The client satisfaction questionnaire-8. In: Maruish ME, editor. The Use of Psychological Testing for Treatment Planning and Outcomes Assessment. 2nd ed. Mahwah, NJ: Lawrence Erlbaum; 1999:1333-1346.

85. Hudak PL, Wright JG. The characteristics of patient satisfaction measures. Spine (Phila Pa 1976). 2000;25(24):3167-3177.

86. Ruggeri M, Lasalvia A, Dall'Agnola R, et al. Development, internal consistency and reliability of the Verona Service Satisfaction Scale European Version. EPSILON Study 7. European Psychiatric Services: inputs linked to outcome domains and needs. Br J Psychiatry Suppl. 2000;39:s41-s48.

87. Weaver M, Patrick DL, Markson LE, Martin D, Frederic I, Berger M. Issues in the measurement of satisfaction with treatment. Am J Manag Care. 1997;3(4):579-594.

88. Bruster S. Seeking the views of consumers using quantitative measures: patient experience surveys. In: Burr J, Nicolson P, editors. Researching Health Care Consumers: Critical Approaches. Basingstoke: Palgrave Macmillan; 2005:55-70.

89. Cleary PD, Edgman-Levitan S. Health care quality. Incorporating consumer perspectives. JAMA. 1997;278(19):1608-1612.

90. Blankertz L, Hazem D. Assessing consumer program needs: advantages of a brief unstructured format. Community Ment Health $J$. 2002;38(4):277-286.

91. Eisen SV. Patient satisfaction and perceptions of care. In: IsHak WW, Burt T, Sederer LI, editors. Outcome Measurement in Psychiatry: A Critical Review. Washington, DC: American Psychiatric Publishing; 2002:303-320.

92. Fitzpatrick R. Capturing what matters to patients when they evaluate their hospital care. Qual Saf Health Care. 2002;11(4):306. 
93. Jenkinson C, Coulter A, Bruster S. The Picker patient experience questionnaire: development and validation using data from in-patient surveys in five countries. Int J Qual Health Care. 2002;14(5):353-358.

94. Larsen DL, Attkisson CC, Hargreaves WA, Nguyen TD. Assessment of client/patient satisfaction: development of a general scale. Eval Program Plann. 1979;2(3):197-207.

95. Reisinger HS, Schwartz RP, Mitchell SG, et al. Premature discharge from methadone treatment: patient perspectives. J Psychoactive Drugs. 2009;41(3):285-296.

96. Mazor KM, Clauser BE, Field T, Yood RA, Gurwitz JH. A demonstration of the impact of response bias on the results of patient satisfaction surveys. Health Serv Res. 2002;37(5):1403-1417.

97. Perneger TV, Chamot E, Bovier PA. Nonresponse bias in a survey of patient perceptions of hospital care. Med Care. 2005;43(4): 374-380.

98. Sitzia J, Wood N. Response rate in patient satisfaction research: an analysis of 210 published studies. Int J Qual Health Care. 1998;10(4): 311-317.

99. Studer J, Baggio S, Mohler-Kuo M, et al. Examining non-response bias in substance use research - are late respondents proxies for nonrespondents? Drug Alcohol Depend. 2013;132(1-2):316-323.

100. Gillespie R. Manufacturing Knowledge: A History of the Hawthorne Experiments. Cambridge: Cambridge University Press; 1991.

101. Sitzia J, Wood N. Patient satisfaction: a review of issues and concepts. Soc Sci Med. 1997;45(12):1829-1843.

102. Sprangers MA, Schwartz CE. Integrating response shift into healthrelated quality of life research: a theoretical model. Soc Sci Med. 1999;48(11):1507-1515.

103. Wilson IB. Clinical understanding and clinical implications of response shift. Soc Sci Med. 1999;48(11):1577-1588.

104. Villar López J, Lizán Tudela L, Soto Alvarez J, Peiró Moreno S. La satisfacción con el tratamiento [Treatment satisfaction]. Aten Primaria. 2009;41(11):637-645. Spanish.

105. Metrebian N, Quirk A, Stimson GV. A model of consumer audit in substance misuse services. J Subst Use. 1997;2(4):222-227.

106. Sixma HJ, Kerssens JJ, Campen CV, Peters L. Quality of care from the patients' perspective: from theoretical concept to a new measuring instrument. Health Expect. 1998;1(2):82-95.

107. Clark CC, Scott EA, Boydell KM, Goering P. Effects of client interviewers on client-reported satisfaction with mental health services. Psychiatr Serv. 1999;50(7):961-963.

108. Coulter A. After Bristol: putting patients at the centre. Qual Saf Health Care. 2002;11(2):186-188.

109. Trujols J, Portella MJ. Not all PROMs reflect patients' perspectives. BMJ. 2013;346:f1552.

110. Hagell P, Reimer J, Nyberg P. Whose quality of life? Ethical implications in patient-reported health outcome measurement. Value Health. 2009;12(4):613-617.

111. Paterson C. Seeking the patient's perspective: a qualitative assessment of EuroQol, COOP-WONCA charts and MYMOP. Qual Life Res. 2004;13(5):871-881.

112. Fraser J. Methadone clinic culture: the everyday realities of female methadone clients. Qual Health Res. 1997;7(1):121-139.

113. Kolind T. Form or content: the application of user perspectives in treatment research. Drugs Educ Prev Policy. 2007;14(3):261-275.

114. Fraser S, Valentine K. Substance and Substitution: Methadone Subjects in Liberal Societies. Basingstoke: Palgrave Macmillan; 2008.

115. Friedman J, Alicea M. Surviving Heroin: Interviews With Women in Methadone Clinics. Gainesville, FL: University Press of Florida; 2001

116. Gourlay J, Ricciardelli L, Ridge D. Users' experiences of heroin and methadone treatment. Subst Use Misuse. 2005;40(12):1875-1882.

117. Gómez J, Latorre A, Sánchez M, Flecha R. Metodología Comunicativa Crítica [Critical Communicative Methodology]. Barcelona: El Roure; 2006. Spanish.

118. Gómez A, Puigvert L, Flecha R. Critical communicative methodology: informing real social transformation through research. Qual Inquiry. 2011;17(3):235-245.
119. Sordé T, Ojala M. Actos comunicativos dialógicos y actos comunicativos de poder en la investigación [Dialogic communicative acts and communicative acts of power in research]. Rev Signos. 2010;43(Suppl 2): 377-391. Spanish.

120. Elbeck M. Patient contribution to the design and meaning of patient satisfaction for quality assurance purposes: the psychiatric case. Health Care Manage Rev. 1992;17(1):91-95.

121. Lozano Rojas OM, Bilbao Acedos I, González Saiz F, Ballesta Gómez R. Dimensiones emergentes para la creación de una escala de percepción del tratamiento con sustitutivos opiáceos [Emergent dimensions for the construction of an opiate substitute treatment perception scale]. Adicciones. 2008;20(1):19-26. Spanish.

122. Trujols J, Portella MJ, Iraurgi I, Campins MJ, Siñol N, de los Cobos JP. Patient-reported outcome measures: are they patient-generated, patientcentred or patient-valued? J Ment Health. 2013;22(6):555-562.

123. Mira JJ. Satisfecho, sí gracias... pero ahora qué? [Satisfied, yes thanks ... but now what?]. Rev Calidad Asistencial. 2003;18(7): 567-569. Spanish

124. Arnstein SR. A ladder of citizen participation. J Am Inst Plann. 1969;35(4):216-224.

125. Friedman SR, Neaigus A, Clatts M. Myths about competence: "Drug users are not competent, public health agencies are". Paper presented at: 8th International Conference on the Reduction of Drug Related Harm; March 1997; Paris, France.

126. Kerr T, Small W, Peeace W, Douglas D, Pierre A, Wood E. Harm reduction by a "user-run" organization: a case study of the Vancouver Area Network of Drug Users (VANDU). Int J Drug Policy. 2006;17(2):61-69.

127. Wood E, Kerr T, Spittal PM, et al. An external evaluation of a peerrun "unsanctioned" syringe exchange program. J Urban Health. 2003;80(3):455-464.

128. Arana X, Germán I. Delimitación del Status Jurídico del Ciudadano 'Consumidor de Drogas'. Propuesta de Carta de Derechos de los Usuarios de Drogas [Delimiting the Legal Status of the Drug-User Citizen. Proposal of a Drug Users'Bill of Rights]. Vitoria: Dirección de Drogodependencias del Gobierno Vasco; 2004. Spanish.

129. Hamilton S, Dale-Perera A, Efthimiou-Mordaunt A, Fry M. Getting Drug Users Involved: Good Practice in Local Treatment and Planning. London: Standing Conference on Drug Abuse; 1997. Available from: http://www.drugscope.org.uk/Resources/Drugscope/Documents/PDF/ Good\%20Practice/Gettinginvolved.pdf. Accessed July 25, 2013.

130. Coupland H, Maher L, Enriquez J, et al. Clients or colleagues? Reflections on the process of participatory action research with young injecting drug users. Int J Drug Policy. 2005;16(3):191-198.

131. Singer $M$. Why is it easier to get drugs than drug treatment in the United States? In: Castro A, Singer M, editors. Unhealthy Health Policy: A Critical Anthropological Examination. Walnut Creek, CA: AltaMira Press; 2004:287-301.

132. Collins JA, Fauser BC. Balancing the strengths of systematic and narrative reviews. Hum Reprod Update. 2005;11(2):103-104.

133. Prilleltensky I. Prólogo. Validez psicopolítica: el próximo reto de la psicología comunitaria [Foreword. Psychopolitical validity: the next challenge for community psychology]. In: Montero M, author. Introducción a la Psicología Comunitaria: Desarrollo, Conceptos y Procesos [Introduction to Community Psychology: Development, Concepts and Processes]. Buenos Aires: Paidós; 2004:5-18. Spanish.

134. Prilleltensky I, Prilleltensky O, Voorhees C. Psychopolitical validity in the helping professions: applications to research, interventions, case conceptualization, and therapy. In: Cohen CI, Timimi S, editors. Liberatory Psychiatry: Philosophy, Politics, and Mental Health. Cambridge: Cambridge University Press; 2008:105-130.

135. Trujols J. Dispositivos, intervenciones y dinámica asistencial: La perspectiva de los usuarios [Substance abuse facilities, interventions and the dynamics of healthcare: The user perspective]. In: Pérez de los Cobos JC, Valderrama JC, Cervera G, Rubio G, editors. Tratado SET de trastornos adictivos [SET Handbook of Addictive Disorders]. Madrid: Médica Panamericana; 2006:463-467. Spanish 
Patient Preference and Adherence

Dovepress

\section{Publish your work in this journal}

Patient Preference and Adherence is an international, peer-reviewed, open access journal focusing on the growing importance of patient preference and adherence throughout the therapeutic continuum. Patient satisfaction, acceptability, quality of life, compliance, persistence and their role in developing new therapeutic modalities and compounds to optimize clinical outcomes for existing disease states are major areas of interest. This journal has been accepted for indexing on PubMed Central. The manuscript management system is completely online and includes a very quick and fair peer-review system. Visit http://www.dovepress.com/ testimonials.php to read real quotes from published authors.

Submit your manuscript here: http://www.dovepress.com/patient-preference-and-adherence-journal 